Pavliuk, T. and Noda, V. (2020), “Analysis of competitiveness and competitive advantages in today's market conditions", Management and entrepreneurship: trends of development, Vol. 2, Issue 12, pp. 91-104, available at:

MARKETING

\section{RECEIVED:}

18 March 2020

ACCEPTED:

28 April 2020

RELEASED:

20 July 2020
UDC 339.137.21

DOI 10.26661/2522-1566/2020-2/12-07

\title{
ANALYSIS OF COMPETITIVENESS AND COMPETITIVE ADVANTAGES IN TODAY'S MARKET CONDITIONS
}

\author{
Tetiana Pavliuk \\ Zaporizhzhia National University \\ Zaporizhzhia, Ukraine \\ ORCID ID: 0000-0001-7480-5475
}

\author{
Veronika Noda \\ Zaporizhzhia National University \\ Zaporizhzhia, Ukraine \\ ORCID ID: 0000-0002-2563-3774
}

*Corresponding author email: pawliuktetiana@gmail.com

\begin{abstract}
The article is devoted to the issues of competitiveness analysis, by which it is possible to evaluate the competitive advantages and disadvantages and to build a strong competitive strategy. The purpose of the article is to research, analyze and identify the main directions of increasing the level of competitiveness of the enterprise under research. The main concepts of enterprise competitiveness are considered in the article and the analysis of the competitive environment of LLC "MIG" LLC is presented. The main factors of influence and competitiveness were revealed and recommendations were given to improve the competitive position of enterprises. The main methods of this study are the methods of empirical research, such as observation, comparison, measurement, as well as abstraction, analysis and synthesis, induction and deduction. Today, technologies have tremendous growth rates, consumer needs are growing with maximum geometric progression, so the task of each enterprise is to be competitive, to have competitive advantages, in order to survive in the world market. Despite the fact that the concept of competitiveness has been studied for a long time, there are issues that need to be studied as quickly as the market allows, in order for enterprises to be able to maximize profits, so the question of competitiveness market analysis is relevant for every enterprise today. In today's global economic development, which is characterized by competition and extremely fast pace of development of the organization, an important component of competition can be considered a vector of orientation to the needs of clients and work in the field of the client. The desire to succeed in customer service is maximized, so there is a growing need for practical guidance on how to focus on customer needs and interests, which will help to maximize competitiveness in the market. The research has practical value, evidenced by recommendations given for improving the competitive position of an enterprise operating in the Ukrainian market by analysing the competitiveness, competitive environment and the vector for its development.
\end{abstract}

Keywords: competitive environment, strategy, competitiveness, development, efficiency, key success factors, competitive advantages.

JEL Classification: L11, M11, D41. 


\section{INTRODUCTION}

In Ukraine and in the world, the problem of finding effective means of enhancing competitiveness comes to the fore, since the active development of economic relations, production, the emergence of new players in the market, changing consumer needs forces us to constantly improve our competitive advantages and to have an effective strategy to compete. The intensification of competition for the most favorable conditions of production and the opportunity to have higher profits forces countries and manufacturers to constantly seek new reserves and opportunities, to innovate, to improve technology, to create better products. In times of crisis, risks and threats to business are increasing sharply, in these circumstances there is a need to adapt to changing conditions, so research into the issue of competitiveness is very relevant today and is important for consideration and research.

\section{LITERATURE REVIEW}

The analysis of the economic literature shows that there is a multidimensional interpretation of the term "competitiveness". Research of theoretical and practical bases of studying the competitiveness of the enterprise on the market were reflected in numerous works of foreign and domestic scientists S. Smerchivsk, I. Ansoff, G. Assel, G. Azoev, I. Ansoff, F. Kotler, G. Mintzberg, Peters, M. Porter, F. Taylor, A. Smith, A. Fayol, R. Fathutdinov, A. Yudanov, and others.

But the question to date remains to determine the theoretical aspects and the positive experience of competitiveness of the enterprise and the factors that influence it, which are not yet well understood and require more in-depth research.

\section{PAPER OBJECTIVE}

The purpose of the study is to study the main directions of increasing the level of competitiveness of the enterprise and the possibility of putting these methods and directions into practice in real competitive conditions.

To achieve this goal, the following tasks were solved: theoretical aspects of the concept of competitiveness, competitive environment of the enterprise are considered, the basic methods of struggle against competition in the enterprise are defined and characterized. The main competitive strategies for the enterprise are analyzed, the organizational and economic characteristics of the activity of the enterprise are conducted, diagnostics of competitiveness of the selected enterprise is carried out. The development of effective mechanism of the ensuring economic security in an integrated manner, were evaluated ways to improve the organization: structural, financial, economic, marketing, substantiation of economic feasibility of implementation of the proposed measures.

\section{METHODOLOGY}

The main methods of this study are the methods of empirical research, such as observation, which was used to study in detail the state of competitiveness of the investigated enterprise. Methods such as comparison, measurement, abstraction, analysis, synthesis, induction and deduction were also used to determine the interdependence between the factors, affecting the level of competitiveness of the enterprise. 
Pavliuk, T. and Noda, V. (2020), “Analysis of competitiveness and competitive advantages in today's market conditions", Management and entrepreneurship: trends of development, Vol. 2, Issue 12, pp. 91-104, available at: https://doi.org/10.26661/2522-1566/2020-2/12-07

\section{RESULTS AND DISCUSSION}

Today any business activity is built on and fully dependent on market relations. The basic concept that defines the essence of market relations is competition. Until the early 1990s, Ukraine was not engaged in research on competition and competitiveness, since there was no practical knowledge, but now, in the face of fierce competition, this issue becomes very relevant. Research, analysis and consideration of the competitiveness of the enterprise is important not only for the enterprise, but also for the economy of the country as a whole, because competitiveness is the key to obtaining high and stable profits, as well as ensuring the viability of the enterprise, its economic security and sustainable development. Therefore, the main task for commodity producers today is to build a completely new and solid competitive strategy that will enable them to compete in domestic economic markets and boldly go beyond their borders while capturing foreign markets.

Analyzing the components of competitiveness, organizations are increasingly turning their attention to a customer-centric approach, namely customer service as a means of achieving competitive advantage.

The relevance of the concept of competition, competitiveness for many centuries is a major issue for economists, managers, marketers from around the world. Researching the work of many scientists, it was determined that competition is a competition, a struggle between players in the economic field for the most favorable conditions of production and sale of goods, for the greatest profits.

Competition forces companies of all forms of ownership to constantly monitor changes in supply and demand, the cost of material resources, reduce production costs, improve the quality of their products and services on the market, increase their competitiveness. So the question of being competitive in the market is important today. What is the concept of competitiveness?

Analyzing the works of scientists who have previously researched this concept and those who are currently engaged in research, these concepts can be combined and presented in a single table.

Table 1

Approaches to defining the concept of "competitiveness" in economic literature

\begin{tabular}{|c|c|}
\hline Author & Definition \\
\hline M. Korinko & $\begin{array}{l}\text { The competitiveness of an organization is defined as the ability of a } \\
\text { firm to produce competitive products, an advantage of the firm in } \\
\text { relation to other firms of the given industry domestically and abroad } \\
\text { (Korin'ko M. D., 2003) }\end{array}$ \\
\hline R. Gretzky & $\begin{array}{l}\text { Competitiveness is a factor or combination of factors that makes an } \\
\text { organization more successful than its competitors in a competitive } \\
\text { environment and cannot easily be repeated by competitors } \\
\text { (Hretskyi R. L., 2007) }\end{array}$ \\
\hline D. Mylenky & $\begin{array}{l}\text { Competitiveness is the ability to better meet existing or emerging needs } \\
\text { in the region (Milenkyi D. V., 2008) }\end{array}$ \\
\hline $\begin{array}{l}\text { E. Boguslavsky, } \\
\text { Y. Shibalkina }\end{array}$ & $\begin{array}{l}\text { Competitiveness is considered as the role of the region and its place in } \\
\text { the economic space of the country, the ability to provide a high } \\
\text { standard of living for the population and the opportunity to realize the } \\
\text { potential that the region possesses (Boguslavsky E. I. and } \\
\text { Shibalkina Y.S., 2009) }\end{array}$ \\
\hline S. Smerchivska & $\begin{array}{l}\text { Competitiveness is defined as determined by the economic, social, } \\
\text { political and other factors of the situation of the region and its } \\
\text { individual producers in the internal and external markets, which is } \\
\text { reflected through indicators (indicators), adequately characterizing the } \\
\text { state and dynamics (Smerichivska S. V., 2009) }\end{array}$ \\
\hline
\end{tabular}


Today, the competitiveness of an enterprise is one of the most important tasks for all enterprises that work and compete with each other. The main task should be research and analysis of competitiveness.

Ensuring the competitiveness of the enterprise - is a set of sequential actions of the management subsystem, the sphere of provision (information, scientific, legal, regulatory resource) that exert mutual influence on the managed subsystem (technical, technological, social, labor, organizational, economic, financial and investment components) competitiveness in the market.

Management of enterprise competitiveness requires restructuring of the whole management system, and especially its strategic part. At the present stage, the functions of competitiveness management are implemented in five stages: planning activities in the field of competitiveness, organizing the process of motivating employees who carry out the processes of controlling and regulating the process of ensuring the competitiveness of the enterprise.

The issue of competitiveness assessment has been repeatedly considered in fundamental scientific works, but to date no unified methodology for assessing the competitiveness of an industrial enterprise has been developed.

What is the purpose of assessing the competitiveness of an enterprise? The main objective is to identify and evaluate the factors that affect consumers' attitude to the enterprise and its products and which allow to compete with and win over other producers. The competitiveness of an enterprise should only be assessed by comparing the conditions, resources and performance of an enterprise with a particular group of enterprises that are recognized by its competitors.

In order to properly analyze and investigate an enterprise, it is necessary to carry out a complete diagnosis of it.

It is important to diagnose internal potential and external market factors that directly affect the competitive environment. Such diagnostics refers to the method of "qualitative" assessment of the competitiveness of the enterprise, they include: SWOT-analysis, SNW-analysis, PEST-analysis. According to the SWOT analysis, the analysis of environmental factors of indirect and direct influence (opportunities, threats), as well as the analysis of environmental factors of the enterprise (advantages, weaknesses). SNW analysis with the help of this analysis it is possible to analyze the factors of the internal environment of the enterprise. PEST-analysis to carry out an analysis of environmental factors of indirect impact on the enterprise, depending on its industry characteristics (Baryshpol, N. and Bondarenko, S., 2017).

Each enterprise must evaluate and analyze its financial and economic status. It is possible to use the method of express diagnostics to evaluate the financial and economic condition of the enterprise. This method is used to obtain prompt information on identifying indicative deviations from economic activity by calculating key indicators and, accordingly, performing ambulance to the enterprise. The system of rapid diagnostics allows to identify the problematic moments and to investigate the critical situations of the enterprise, to identify the signs of development of the entrepreneurial crisis and to provide recommendations for its prevention. Used for rapid diagnostics accounting, statistical and financial reporting of the company (Baryshpol, N. and Bondarenko, S., 2017).

In practice, enterprises cannot apply all the recommended coefficients that are included in the system of rapid diagnostics, so the most indicative indicators, which characterize the financial and economic condition of the business entity, are selected.

The competitiveness of an enterprise is one of the most important categories of a market economy and characterizes the ability and efficiency of adaptation of the enterprise to the conditions of the market environment. Inaccurate or insufficient valuation may result in the company not being competitive enough or not able to compete in the market at all.

The study of competitiveness is the main component of the analysis of the market of competitors, the study of the mechanism of its functioning. In carrying out such an analysis, it is necessary to gather all the basic information about the company, the competitive situation, market 
Pavliuk, T. and Noda, V. (2020), “Analysis of competitiveness and competitive advantages in today's market conditions", Management and entrepreneurship: trends of development, Vol. 2, Issue 12, pp. 91-104, available at: https://doi.org/10.26661/2522-1566/2020-2/12-07

factors and the results of their action, and one of the important points is the need to characterize the structure and determine the components and factors of the competitive environment.

One approach to assessing competitiveness research based on competitive advantage theory developed by M. Porter. Where the level of competition depends on five components (Porter, 2008):

- threats of substitute products;

- threats of new players;

- the market power of suppliers;

- consumer market power;

- the level of competition

There are methods for evaluating an enterprise based on evaluating an enterprise's marketing strategy based on building a matrix of competitive strategies.

The essence of the assessment lies in the analysis of the matrix, constructed on the basis of the coordinate system: horizontally - the rate of growth (reduction) of sales; vertically - the relative share of the enterprise in the market. Most competitive are those with a significant share of the fastgrowing market.

Of course, research and analysis of the enterprise on competitiveness plays a significant role in the further development of the enterprise, industry, products as a whole.

In addition to the necessary actions listed above, an important component is identifying key success factors as one without which no competitive strategy can be built.

The key success factors in an industry (KSF) are the strengths and capabilities of an enterprise, the skillful use of which will provide it with high competitiveness and profitability in the strategic period. KSF businesses in different industries vary and even in the same industry change over time. There are KSF of the industry and KSF of this enterprise. The number of KSFs in the industry does not exceed three to four, of which only one or two are most important (Saienko M. H., 2006; Bakaj V. J., 2016).

KSFs depend on:

a) technology and innovation;

b) the state of production (quality, cost, the level of resources of supply and efficiency of their use, etc.);

c) the level of marketing;

d) sales opportunities and skills (sales network, sales costs, etc.);

e) professional level of staff;

e) organizational capabilities (information systems,

modern management, etc.);

g) other factors (image, commitment of local authorities, access to financial markets, favorable natural conditions and location, etc.).

After rapid diagnostics of the enterprise, research of competitiveness, analysis of marketing strategy, carrying out "qualitative" diagnostics and determination of CFU of the industry, the next important step is to identify and evaluate competitive advantages.

The main difference between most Ukrainian enterprises, and especially industrial ones, from their foreign competitors is that they are several times less efficient and capital-intensive. Of course, for the formation of their own competitive advantages, you must either invest in the development of as many resources as foreign competitors, which is very problematic, or concentrate their resources only on the most promising areas of activity. Therefore, a rapid increase in the level of competition in the domestic and foreign markets leads to the competitiveness of those enterprises that will have competitive advantages in all areas, namely: in reducing costs, improving the quality and expansion of product range, ensuring production flexibility, increasing profitability, implementation innovation, knowledge development and more. The competitive advantage of the enterprise depends directly on the competitive advantages of the products. Figure 1 shows the direct dependence of an enterprise's competitive advantage on its competitive advantage. 


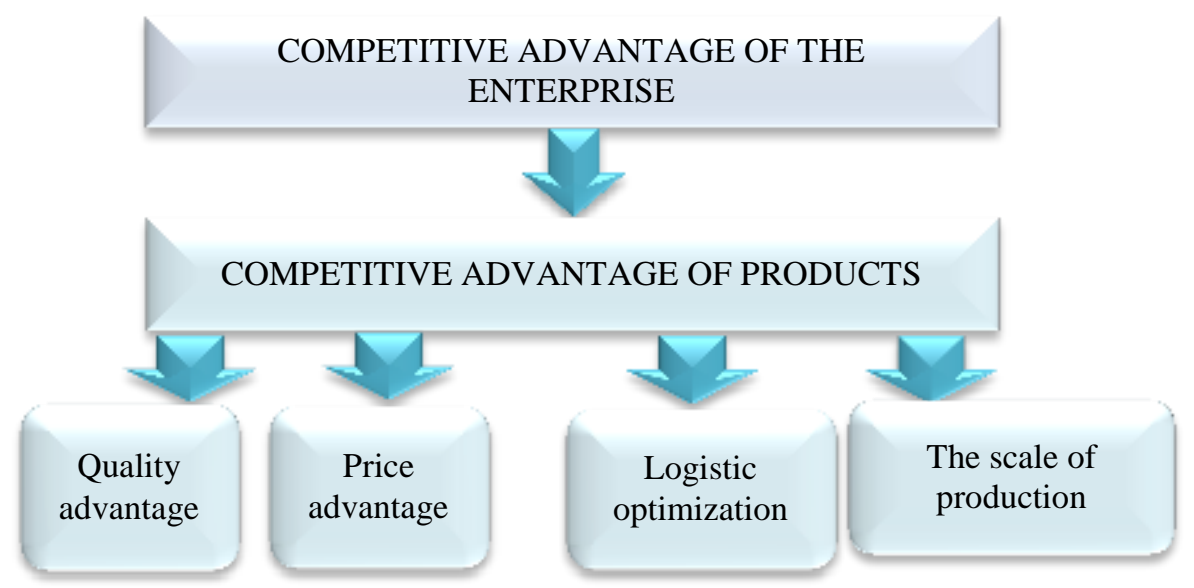

Figure 1. The direct dependence of the competitive advantage of the enterprise on the competitive advantages of products

Source: modified after (Tsvok, D. R. and Yavorska, N. P. (2017)

After exploring the main methods of competitive advantage of the enterprise and analyzing possible ways of assessing the competitiveness, it is further necessary to apply these methods and ways in practical experience. The object of research was selected for the analysis and evaluation of LLC MIG, a company operating in the market of Ukraine in Zaporizhzhia, whose main activity is the production and sale of LED products. In this direction, the industry analyzed the possible competitors, which in turn were allocated to strategic groups. Tables 2 and 3 identify the main competitors and are distributed by attribute to build a strategic group.

Table 2

The main competitors of the enterprise of the Scientific-Production Company "MIG"

\begin{tabular}{lcc}
\hline \multicolumn{1}{c}{ Company } & Assortment & Geographic scale of activity \\
\hline LLC "NVP MIG" & Narrow & Narrow \\
PE “Zyabkin" & Narrow & Narrow \\
Monolit-LTD LLC & Narrow & Narrow \\
Sintez-Led Company & Average & Narrow \\
Southern Industrial Company LLC & Average & Wide \\
KP "Misksvit" & Average & Narrow \\
\hline
\end{tabular}

Source: own compilation

Table 3

Background for building a map of strategic groups

\begin{tabular}{llcc}
\hline № & \multicolumn{1}{c}{ Company } & Markets & $\begin{array}{c}\text { Product } \\
\text { Certification }\end{array}$ \\
\hline 1 & LLC "NVP MIG” & Wholesale & + \\
2 & PE “Zyabkin” & Retail & + \\
3 & Monolit-LTD LLC & Wholesale & + \\
4 & Sintez-Led Company & Retail & + \\
5 & Southern Industrial Company LLC & Wholesale & + \\
6 & KP "Misksvit” & Wholesale & \\
\hline
\end{tabular}

Source: own compilation 
Pavliuk, T. and Noda, V. (2020), “Analysis of competitiveness and competitive advantages in today's market conditions", Management and entrepreneurship: trends of development, Vol. 2, Issue 12, pp. 91-104, available at: https://doi.org/10.26661/2522-1566/2020-2/12-07

In Figures 2 and 3 these competitors are divided into strategic groups by characteristics.

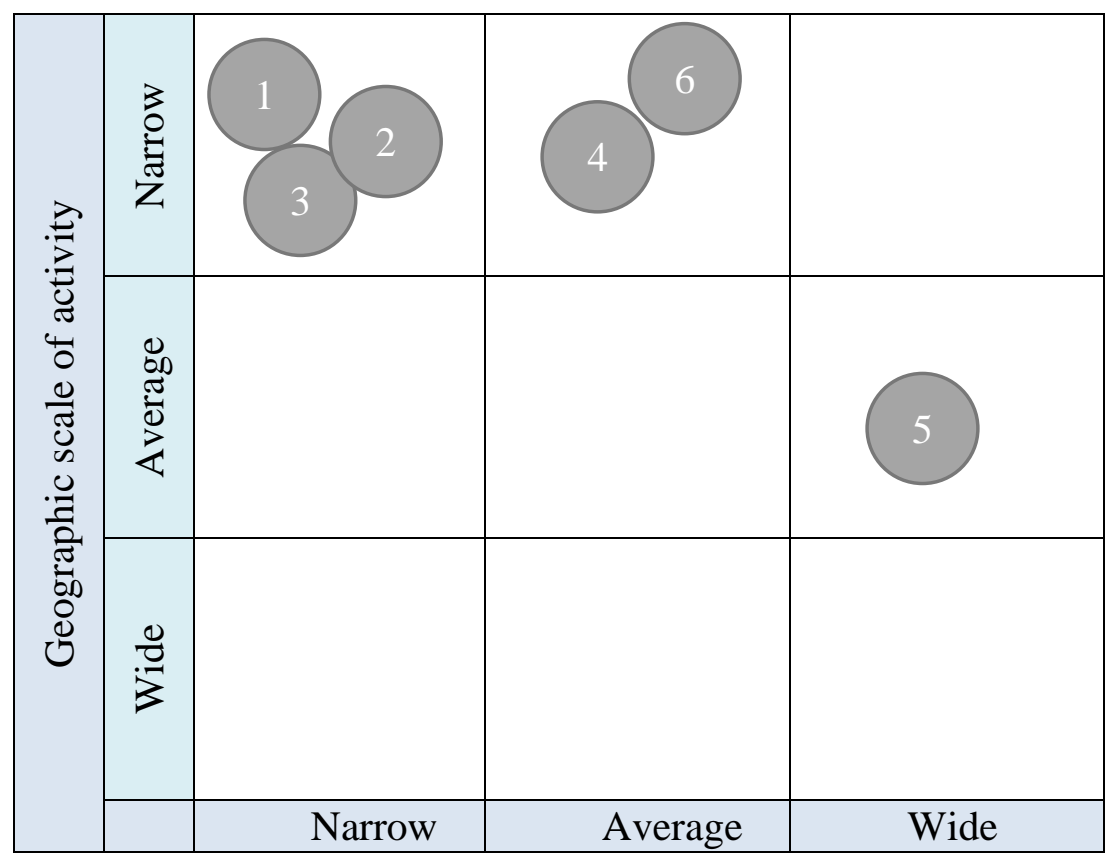

Figure 2. The competitors which divided into strategy

Source: own compilation

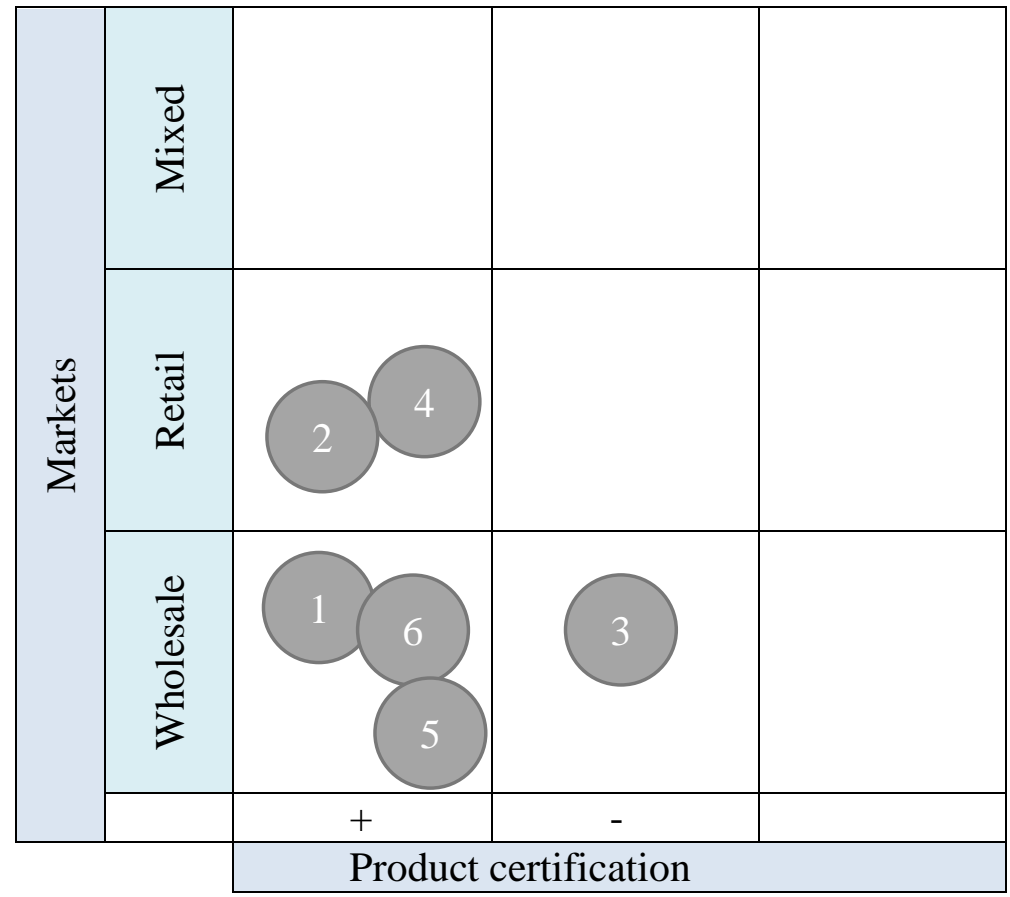

Figure 3. The strategic groups characteristics

Source: own compilation 
Therefore, for this enterprise the largest players in the market are KP "Misksvitlo", LLC "Southern Industrial Company”, PE “Zyabkin”, LLC "Monolith-LTD”.

Further, for conducting full diagnostics and analysis of competitiveness of the enterprise an analytical description of the organization, its branch affiliation, real directions of activity, analyzed stages of development of the enterprise, its organizational structure, financial and economic analysis were carried out. Competitors, the evaluation of the marketing strategy, the method of M. Porter gave an assessment of competitiveness, both enterprise and industry, pro implemented by the KSF in the industry.

According to the results obtained, NIG "MIG" is: not a state-owned trading enterprise, this enterprise is a small, profitable, formal enterprise with imperfect linear organizational structure that has undergone two complete stages of development and is in the stage of youth development (i.e. in the transitional period) the growth of the organization is, as a rule, unsystematic, by jerks; the organization is increasingly gaining ground, but coordination is below the optimum level; there are significant threats: liquidity shortages, difficult access to credit. Analyzing the organizational structure of management, it was concluded that the structure is linear and imperfect, because the staff is not adequately staffed in some departments, and there are not enough specialists in the field of marketing, accounting, HR, and there are no IT specialists at all.

Analyzing the share of personnel in the two reporting years (2018-2019), we can say that the share of executives has increased, but the share of workers, specialists and employees, on which the main profit of the enterprise depends, remained unchanged. The share of non-industrial personnel, which is not basic in the enterprise, remained constant.

According to the financial and economic indicators, this company has financial difficulties. The ratio of financial independence of the enterprise shows a steady tendency from 2014 to decrease, which means that the enterprise has practically no own funds and needs constant external sources of financing, may be insolvent and be in the risk zone. In the case of the surveyed enterprise, we see that the coefficient of dependence also increased significantly during 2014-2018, which indicates the dependence of the company on external investors and creditors, and we can also speak about some decrease in financial stability. Analyzing the profitability indicators, we noticed that the profitability indicators are decreasing. In 2014, the loss of activity was $11.60 \%$, while in 2018 it was $6.89 \%$. This indicates that the company has chosen a strategy for economic growth, but it is imperfect and does not work in full.

The SWOT-analysis made it possible to draw attention to the fact that the company's opportunities are related to the economic development of the state and with the increase of financing of state and municipal institutions, increase of demand for innovative products, entering other markets of the country. Threats to the company may be due to the planned increase in the dollar, a decrease in the investment attractiveness of the country, a decrease in demand for trading equipment, the activation of existing competitors, a shortage and an increase in the cost of financial resources.

Strengths are strong customer base, constant partners, flexibility of the price offer, and certification of the goods. But there are also threats from the weaknesses: lack of innovative activity of the enterprise, low marketing activity, lack of representative offices in the regions of the country and abroad, lack of FEA, lack of customer incentive system, poor organizational and management structure.

Assessing the competitiveness of this enterprise, we saw that NVP MIG LLC is in a very strong competitive circle. The market is saturated with commodities-substitutes, the products of the enterprise lack unique characteristics. The products have an average level of quality and competitive price. The company market is highly competitive. There is a high risk of losing customer base. The threatening position of new products and players in the market of this industry. We need to constantly analyze the market situation and make flexible decisions to improve the situation. 
Pavliuk, T. and Noda, V. (2020), “Analysis of competitiveness and competitive advantages in today's market conditions", Management and entrepreneurship: trends of development, Vol. 2, Issue 12, pp. 91-104, available at: https://doi.org/10.26661/2522-1566/2020-2/12-07

Improvement of financial results can be achieved by establishing close relationships with intermediaries, implementing a low-cost strategy, social and organizational development, implementing innovative technologies, developing low-cost and cost-effective measures, etc.

Considering the analysis and research that was carried out for this company, we can conclude that a strong competitive strategy is needed, taking into account the data that has been obtained. Therefore, a strategy was proposed to improve the competitiveness of the enterprise, which included all the necessary steps, starting with the financial and economic and ending with the restructuring of the organizational structure of management. These steps are described in more detail below.

In view of the financial and economic indicators, LLC NVP MIG is unprofitable. The reason is insufficient demand for products. The company does not fully meet the needs of consumers and potential partners. Therefore, consumer needs analysis allows us to target the production and sale of LED products in yet another innovative vector of direction - these are the design built-in LED lamps.

The yield index for the proposed innovations was calculated to be more than one. This means that this investment project can be accepted and considered profitable. Next, the effectiveness of the proposed measures and the payback period were calculated. The payback period was 3.5 months. Therefore, these measures are profitable and can be boldly implemented to bring the enterprise out of the crisis and as those that will help the enterprise to be competitive.

The next strategic step to increase the enterprise's competitiveness will be to change the organizational structure.

Suggestions to address these shortcomings:

- improve the structure of the organization: add two specialists to the personnel department in order to reduce the burden on the director and free up time for other, more strategic work;

- hire two specialists in the marketing department to achieve the goals and objectives of internal marketing, to analyze the competitive environment, to strengthen long-term interactions with clients, to attract new ones;

- to add to the technical department of the IT-specialist for protection of economic and other data, not to waste time to search for this specialist if necessary;

- add a specialist to the accounting department and differentiate responsibilities;

- empower heads of departments to make strategic decisions;

- to add a specialist to the production department for unloading middle management levels, this will allow for a more balanced and expedient implementation and planning of the department's activities.

With regard to strengthening positions in the competitive market, the following measures were proposed:

- improving marketing activities - give maximum attention to research, analysis and forecasts of the competitive environment, namely: analysis of the reasons for the success of competitors, analysis of market proposals, pricing policy throughout the year, production and sales opportunities, analysis of equipment upgrades, possible innovations, market share.

- increase of "service" parameters - in this regard, it is necessary to improve the payment terms for large partner firms in deferred payment. Another means of increasing "service" is the wider application of the discount system.

- improvement of the personnel management system - staff incentives (bonuses, promotions, insurance, trade unions for employee rights protection, teambuilding), organizational culture (initiate values, standards of behavior, treating the company as a business, introducing an open door culture, staff development (trainings), refresher courses)

- reducing the cost of LED products - first of all, it is the search for such companies that sell consumables of impeccable quality, but at a cheaper price than regular sellers. The best option is to go without intermediaries and establish direct contacts directly with the manufacturers. 
- improvement of the production system - improve the structure of investments in the enterprise. To carry out a complex of measures for updating and modernization of the equipment, having purchased modern professional equipment.

- introduction of innovations.

The next step to increase the competitiveness of this company is to research and improve the customer-oriented approach.

In markets where competition is getting stronger every year, those organizations that are focused on the needs of customers and clients in general show the best result of their activities. For example: a Tesco retailer has been able to increase its profitability and share in the turnover of the market and to win the leading position in the competitive market, Levis has a special section in the store where you can change the product to your taste, thanks to which the company has increased sales in several times.

First of all, a strategy was developed to retain regular customers by developing loyalty programs, value to the client throughout the life of him (willingness to help, ability to solve problems, reliability, quality).

The next step is to provide $24 / 7$ online customer support to help your organization get the following benefits:

1. Ability to sell products faster

2. Ability to establish customer feedback.

It helps create more sophisticated products and build customer loyalty.

The customer-centric approach was based on both positive and negative feedback, i.e. it was suggested to create a department (online resource) for customer feedback, which is customer care, which in turn leads to better quality of service. Also, through the Internet, the organization has the opportunity to conduct surveys of the degree of customer satisfaction online each time with the opportunity to choose different criteria.

The first online survey was conducted in the service sector, and the ability to listen to a client is Table 4.

Table 4

Online customer survey results

\begin{tabular}{lccc}
\hline \multicolumn{1}{c}{ Service } & Importance (\%) & Efficiency (\%) & $\begin{array}{c}\text { Difference between } \\
\text { expected and actual } \\
\text { results (\%) }\end{array}$ \\
\hline $\begin{array}{l}\text { Attention given to the } \\
\text { client }\end{array}$ & 68 & 47 & -21 \\
$\begin{array}{l}\text { Fast product selection } \\
\text { Reservation }\end{array}$ & 66 & 47 & -19 \\
Urgent return & 88 & 77 & -11 \\
\hline
\end{tabular}

\section{Source: own compilation}

This survey shows that special attention should be paid to the two needs of clients - this is a reservation by reservation and an early return.

Many organizations use standard benchmarking methods, in addition to standard customer survey and listening methods, to help document the causes of the differences and identify the necessary actions that allow competitors to be the best in the category and outperform them by developing an action plan.

There are four basic methods of benchmarking:

1. With direct competitors

2. With parallel industries 
Pavliuk, T. and Noda, V. (2020), “Analysis of competitiveness and competitive advantages in today's market conditions", Management and entrepreneurship: trends of development, Vol. 2, Issue 12, pp. 91-104, available at: https://doi.org/10.26661/2522-1566/2020-2/12-07

3. With other units of your organization

4. With other industries or organizations as the best in this category.

The strategy-process of comparative analysis of LLC "NVP MIG" was developed for the correct use of the method of comparative analysis (Figure 4).
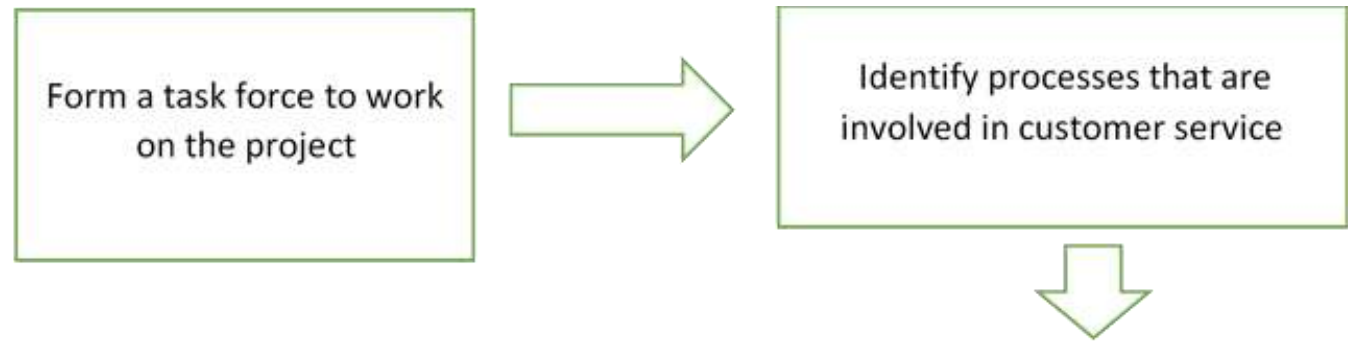

Identify participants in the benchmarking of internal, external, industry representatives, or the best
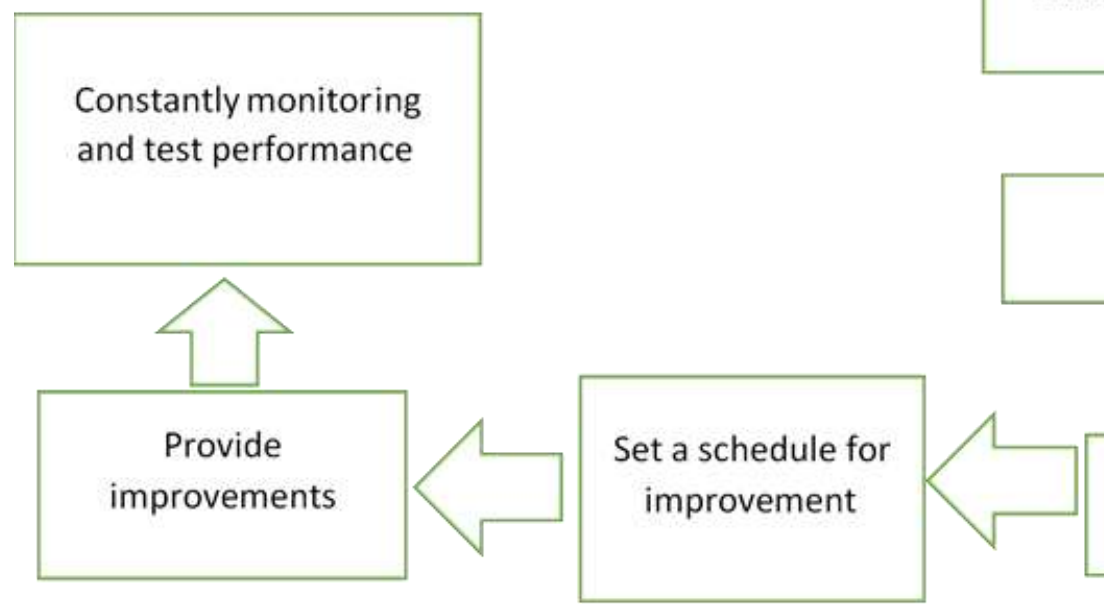
in this category

Figure 4. The strategy-process of comparative analysis of LLC "NVP MIG"

\section{Source: own compilation}

Therefore, businesses need to constantly enhance the quality of service as they undertake long-term customer responsibilities. It can be assumed that only those companies that have a customer-oriented approach will retain their competitive advantage and will be constantly improving.

\section{CONCLUSION}

The ultimate goal of enhancing a company's competitiveness is to increase profitability and expand its sales market, increase its market share and ensure sustainability.

Therefore, all these measures will help NPP MIG to be competitive on the market, overcome the financial and economic crisis and become successful.

Analyzing all the actions that have been proposed to analyze and research the competitiveness of the enterprise, as well as the significant changes that have been developed to increase the competitiveness of the real enterprise, both in the management of the enterprise, in the control of marketing strategy and in the implementation of innovations, make it possible to assure that competitive strategy, methods of struggle, relationships with competitors is important and must be 
constantly researched and improved to ensure competitive advantages of enterprises and "healthy competitive climate" in the market competition.

\section{REFERENCES}

Afanas'iev, M. V. and Bilokonenko, H.V. (2007), Ekonomichna diahnostyka [Economic diagnostics]. VD «INZhEK», Kharkiv, (in Ukrainian).

Bakaj, V. J. (2016), Competitiveness of the enterprise, available at: https://dn.khnu.km.ua/dn/k_default.aspx?M=k1311\&T=03\&lng=1\&st=0～(Accessed 18 November 2019), (in Ukrainian).

Baryshpol, N. and Bondarenko, S. (2017), "Approaches to the evaluation of competitiveness enterprise", Efektyvna ekonomika, Issue 5, available at: http://www.economy.nayka.com.ua/?op=1\&z=5610 (Accessed: 18 November 2019), (in Ukrainian).

Boguslavsky, E.I. and Shibalkina, Y.S. (2009), "Strategy of diversification : choice of time start", Social Economy, Vol. 2, pp. 182-188, (in Ukrainian).

Hretskyi, R. L. (2007), "Theoretical approaches to determining the nature and essence of competition", Formuvannya rynkovych vidnosyn v Ukrayini, Vol. 12, pp. 35-38 (in Ukrainian).

Karachyna, N. P. and Pertsata, L. I. (2014), "Competitive potential and its role in formation of the enterprise competitiveness", Economic scope, Issue 86, pp. 164-172, (in Ukrainian).

Klymenko, S. M., Omel'ianenko, T. V., Barabas', D. O., Dubrova, O. S. and Vakulenko, A. V. (2008), Upravlinnia konkurentospromozhnistiu pidpryiemstva [Management of enterprise competitiveness]. KNEU, Kyiv, (in Ukrainian).

Korin'ko, M. D. (2003), "Diversification in the history of economic thought", Aktual'ni problemy ekonomiky, Issue 1, pp. 2-5, (in Ukrainian).

Kvasnyts'ka R. and Ardashkina N. (2012), "Competitive potential: economic nature and elemental composition", Ekonomichnyy analiz, Vol. 10(4), pp. 161-164, (in Ukrainian).

Milenkyi, D. V. (2008), "The choice of competitive business strategy using decision tree", Visnyk Donetskogo natsionalnogo universytetu ekonomiky torgivli imeni Mykhaila TuhanBaranovskogo, Vol. 4, pp. 9-17, (in Ukrainian).

Noda, V. F. (2019), "Competitive potential of Zaporizhzhia region", Conference Proceedings of the All-Ukrainian Scientific and Practical Conference, Problems of the management of the regional economic potential, ZNU, Zaporizhzhia, p. 38.

Porter, M. E. (2008), "The Five Competitive Forces That Shape Strategy", Special Issue on HBS Centennial, Harvard Business Review 86, Issue 1, pp. 78-93.

Pynnönen, M., Ritala, P. and Hallikas, J. (2011), "The new meaning of customer value: a systemic perspective", Journal of Business Strategy, Vol. 32(1), pp.51-57, available at: http://dx.doi.org/10.1108/02756661111100328 (Accessed: 11 December 2019), DOI: $10.1108 / 02756661111100328$

Saienko, M. H. (2006), Stratehiia pidpryiemstva [Enterprise strategy]. Ekonomichna dumka, Ternopil' (in Ukrainian).

Shay, J. and Rothaermel, F. (2000), "Dynamic Competitive Strategy: Towards a Multiperspective Conceptual Framework", Long Range Planning, Vol. 32(6), pp. 559-572, available at: http://dx.doi.org/10.1016/s0024-6301(00)00017-0 (Accessed: 26 October 2019), DOI: 10.1016/s0024-6301(00)00017-0

Smerichivska, S. V. (2009), "Competitiveness in social and economic terms", Aktualni problem ekonomiky, Vol. 3, pp. 36-45, (in Ukrainian).

Tsvok, D. R. and Yavorska, N. P. (2017), "Formation of competitive advantages of the enterprise", Problems of systematic approach in economy, Vol. 5, Issue 61, pp. 141-147, available at: 
Pavliuk, T. and Noda, V. (2020), “Analysis of competitiveness and competitive advantages in today's market conditions", Management and entrepreneurship: trends of development, Vol. 2, Issue 12, pp. 91-104, available at: https://doi.org/10.26661/2522-1566/2020-2/12-07

http://psae-jrnl.nau.in.ua/journal/5_61_2017_ukr/22.pdf (Accessed: 10 December 2019), (in Ukrainian).

Unceta, A., Castro-Spila, J. and García Fronti, J. (2016), "Social innovation indicators", Innovation: The European Journal of Social Science Research, Vol. 29(2), pp. 192-204, available at: https://doi.org/10.1080/13511610.2015.1127137 (Accessed: 11 December 2019), DOI: $10.1080 / 13511610.2015 .1127137$

\section{АНАЛІЗ КОНКУРЕНТОСПРОМОЖНОСТІ ТА КОНКУРЕНТНИХ ПЕРЕВАГ В СУЧАСНИХ РИНКОВИХ УМОВАХ}

\author{
Павлюк Тетяна Сергіївна \\ Запорізький національний університет \\ м. Запоріжжя, Украӥна
}

\author{
Нода Вероніка Федорівна \\ Запорізький начіональний університет \\ м. Запоріжжя, Украӥна
}

Стаття присвячена питанням аналізу конкурентоспроможності, за допомогою якого можливо в повній мірі оцінити переваги, недоліки, ризики та побудувати міцну конкурентну стратегію, базуючись на конкурентних перевагах в сучасних ринкових умовах. Висвітлено основні методи конкурентного аналізу, їх недоліки та переваги, визначено найефективніші методи оцінки конкурентних переваг. Сьогодні технології мають неабиякі темпи зростання, потреби споживачів ростуть 3 максимальною геометричною прогресією, тому задача кожного підприємства буди конкурентним, мати конкурентні переваги, для того, щоб вистояти на світовому ринку. Незважаючи на те, що поняття конкурентоспроможності вивчається достатньо давно, є питання які повинні вивчатися так швидко, як це дозволяє ринок, для того, щоб підприємства мали можливість отримати максимальні прибутки, тому питання аналізу ринку конкурентоспроможності на сьогодні актуальне для кожного підприємства. Метою статті $\epsilon$ окреслення основних напрямків підвищення рівня конкурентоспроможності підприємства та можливості втілення даних методів та напрямків на практиці в реальних конкурентних умовах. Основними методами цього дослідження $€$ методи емпіричного дослідження, такі як спостереження, порівняння, вимірювання, а також абстрагування, аналіз та синтез, індукція та дедукція. За результатами дослідження було зроблено висновки про позитивний вплив таких процесів як, проведення маркетингового аналізу, конкурентного аналізу, введення інновацій вивчення питання конкурентної стратегії, методів боротьби, взаємозв'язків з конкурентами, на конкурентоспроможність підприємства. Наукове та практичне значення роботи. Дослідження має практичну цінність, про що свідчать певні рекомендації, щодо поліпшення конкурентної позиції підприємства, що працює на ринку України шляхом аналізу конкурентоспроможності, конкурентного середовища та правильного вектору на розвиток даного підприємства.

Ключові слова: конкурентне середовище, стратегія, конкурентоспроможність, розвиток, ефективність, ключові фактори успіху, конкурентні переваги.

\section{АНАЛИЗ КОНКУРЕНТОСПОСОБНОСТИ И КОНКУРЕНТНЫХ ПРЕИМУЩЕСТВ В СОВРЕМЕННЫХ РЫНОЧНЫХ УСЛОВИЯХ}

\author{
Павлюк Татьяна Сергеевна \\ Запорожский национальный университет \\ 2. Запорожье, Украина
}

\author{
Нода Вероника Фёдоровна \\ Запорожский национальный университет \\ 2. Запорожье, Украина
}

Статья посвящена вопросам анализа конкурентоспособности, с помощью которого возможно в полной мере оценить преимущества, недостатки, риски и построить прочную конкурентную стратегию, основываясь на конкурентных преимуществах в современных рыночных условиях. Освещены основные методы конкурентного анализа, их недостатки и 
преимущества, определены наиболее эффективные методы оценки конкурентных преимуществ. Сегодня технологии имеют серьезные темпы роста, потребности потребителей растут с максимальной геометрической прогрессией, поэтому задача каждого предприятия быть конкурентным, иметь конкурентные преимущества, для того, чтобы выстоять на мировом рынке. Несмотря на то, что понятие конкурентоспособности изучается достаточно давно, есть вопросы, которые должны изучаться так быстро, как того требует рынок, чтобы предприятия имели возможность получить максимальные прибыли, поэтому вопрос анализа рынка конкурентоспособности на сегодня актуален для каждого предприятия. Целью статьи является определение основных направлений повышения конкурентоспособности предприятия и возможности воплощения данных методов и направлений на практике в реальных конкурентных условиях. Основными методами этого исследования является методы эмпирического исследования, такие как наблюдение, сравнение, измерение, а также абстрагирование, анализ и синтез, индукция и дедукция. По результатам исследования были сделаны выводы о положительном влиянии таких процессов как, проведение маркетингового анализа, конкурентного анализа, введение инноваций изучения вопроса конкурентной стратегии, методов борьбы, взаимосвязей с конкурентами, на конкурентоспособность предприятия. Научное и практическое значение работы. Исследование имеет практическую ценность, о чем свидетельствуют определенные рекомендации по улучшению конкурентной позиции предприятия, работающего на рынке Украины путем анализа конкурентоспособности, конкурентной среды и правильного вектора на развитие данного предприятия.

Ключевые слова: конкурентная среда, стратегия, конкурентоспособность, развитие, эффективность, ключевые факторы успеха, конкурентные преимущества. 